Щербакова Л.в.

\title{
Влияние статуса одариваемого на выбор подарка женщинами-руководителями
}

Понятие «подарок» появилось, когда человек еще только учился быть человеком. Выстраивая отношения с себе подобными, он открывал смысл доброты, радушия, испытывал признательность за чужую заботу и отзывчивость. Способом выразить эти чувства становился подарок. В русском языке у этого слова есть еще и братблизнец: «гостинец», от слова «гость». Это значит, что по обычаю человек входил в дом с подарком, и его готовы были в этом доме отдарить.

Обзор исследований в области психологии показал, что процесс дарения практически не изучен, более того, такое явление, как подарок еще не стало предметом различных социально-психологических работ. Вместе с тем необходимо отметить, что процесс дарения сопровождает различные аспекты жизнедеятельности человека, что уже на уровне обыденного поведения становится понятной существенная роль подарка в разнообразных ситуациях взаимодействия.

Особенностью изучения подарка с точки зрения антропологии, истории, культурологии является то, что изучается не столько сам подарок, сколько процесс дарения (Ю.Лотман, Б.Малиновский, М.Мосс, Тахо-Годи, М.Энафф и др.). В.Ильин считает, что интерес к подарку как к предмету исследования впервые возник именно в рамках традиционной антропологии [1]. Основы изучения этого феномена были заложены Марселем Моссом. В основополагающей работе об исследовании процесса дарения «Эссе о даре» М.Мосс изложил основные принципы этого процесса [3]. Как пишет М.Мосс, основой древнейшего обычая обмена подарками является принцип «взаимности». По его мнению, делать подарки, принимать подарки, делать ответные дары - это в равной степени важные обязанности, которые должны неукоснительно выполняться. Вручение подарка имеет целью породить дружеские чувства. Подарок - вещь, которая должна доставить удовольствие получателю. С одной стороны, обмен подарками - дело добровольное, но, с другой стороны эта добровольность достаточно условна. Отказ от обычаев дарения и ответного дарения эквивалентен объявлению войны, отказу от союза.

Мы рассматриваем подарок как средство, сопровождающее различные ситуации взаимодействия между людьми. Проанализировав исследования, посвященные изучению подарка и процессу дарения, мы можем дать следующее определение подарку с точки зрения социальной психологии. Подарок - это средство социальной коммуникации, направленной на установление желаемого типа отношений и удовлетворения социальных потребностей в определенной системе статусноролевого взаимодействия. Для того, чтобы подарок выполнял роль «радостного события», он должен преподносится по собственной воле дарителя; удовлетворять потребностям получателя, соответствовать его самооценкам, уровню притязаний, статусу и роли; быть знаком, символом бескорыстия. 
Изучая подарок с точки зрения гендерной идентичности личности, можно сказать следующее: традиционное восприятие «женского» и «мужского» влияет на выбор подарка и отношение к подарку. Определенные вещи принято дарить только женщинам, и наоборот. Женщинам чаще дарят подарки, чем мужчинам. Как считает Г.Карпова, это связано с подсознательным стереотипом, который своими корнями уходит в далекое прошлое: мужчина - добытчик и воин, он сам возьмет то, что ему нужно, и, если захочет, поделится этим с женщиной [2].

С другой стороны, мужчины и женщины по-разному подходят и к проблеме выбора подарка. По данным американского исследования (Caplow, 1982), женщины дарят намного больше подарков, чем мужчины, зато подарки мужчин - более дорогие.

Получая подарок, мужчины и женщины также ведут себя по-разному. Стереотипы, характеризующие настоящего мужчину, предполагают, что он не должен говорить о своих эмоциях и переживаниях, поэтому мужчины более равнодушно относятся к самому подарку, - для них более важен процесс дарения. Женщины же очень сильно переживают по поводу подарка и открыто высказывают свои эмоции.

В нашей работе подарок рассматривается в рамках системы отношений между людьми. Классическое определение отношений личности дал В.Н. Мясищев: отношения - целостная система индивидуальных, избирательных, сознательных связей личности с разными сторонами объективной действительности, включающая три взаимосвязанных компонента: отношения человека к людям, к себе, к предметам внешнего мира [4].

Данные представления легли в основу нашего исследования, цель которого заключалась в изучении социально-психологических характеристик подарка в системе деловых отношений (руководители и подчиненные).

В исследовании приняли участие 112 женщин в возрасте от 30 до 50 лет, из них 47 руководителей и 65 подчиненных. С помощью разработанной нами анкеты изучались такие параметры, как: значимость подарка для одаривающего (степень значимости подарков, которые дарят, значение подарка, что он символизирует); виды подарков; гендерная направленность подарка; цели, с которыми дарят подарки; социально-психологические мотивы процесса дарения.

В результате проведенного исследования на основе таких критериев, как значимость подарка для одаривающего, цели, с которыми дарят подарки, социальнопсихологические мотивы процесса дарения, все респонденты были разделены на три группы. В первую группу вошли те, которые подарок и процесс дарения используют с целью изменения отношения к самому себе. Во вторую группу вошли те, которые подарок и процесс дарения используют с целью изменения отношения к другому. В третью группу вошли те, которые подарок и процесс дарения используют с целью изменения отношения к самой ситуации дарения.

В первую группу вошли как руководители, так и подчиненные, но количество руководителей значимо больше, чем подчиненных. Руководители, вошедшие в эту группу, используют подарок для того, чтобы понравиться себе, поддержать 
репутацию, имидж, продемонстрировать свое отличие от других. Во второй и третьей группе подчиненных значимо больше, чем руководителей, Они используют подарок для того, чтобы понравиться другому, привлечь и удержать внимание окружающих, быть адекватным ситуации дарения.

Перейдем к рассмотрению гендерной направленности подарка. Основными мотивами у женщин-руководителей во время преподнесения подарка мужчинам являются получение социального одобрения (мужчине-начальнику), привлечение и удержание внимания (мужчине-коллеге) и поддержание, сохранение или увеличение влияния, власти (мужчине-подчиненному). В то же время женщиныруководители дарят подарки женщинам независимо от их статуса. Они дарят подарки для того, чтобы доставить удовольствие одариваемому.

Основными мотивами при дарении подарков уженщин-подчиненных являются проявить уважение, получить социальное одобрение (начальникам - мужчине и женщине) и чувствовать себя адекватным ситуации, доставить удовольствие одариваемому (коллегам - мужчине и женщине).

Таким образом, в результате проведенного исследования можно сделать следующие выводы.

1. Подарок служит для изменения отношений к самому себе, к другому и к ситуации дарения в целом.

2. Мотивы дарения у женщин-руководителей зависят от пола одариваемого, а у женщин-подчиненных - от статуса одариваемого.

\section{Литература}

1. Ильин В. Подарок как социальный феномен. www.acapod.ru

2. Карпова Г. Гендерные аспекты феномена подарка. www.socnet.narod.ru

3. Мосс Марсель Эссе о даре. - СПб: Евразия, 2000.

4. Мясищев В.Н. Психология отношений. - Москва-Воронеж, 1995. 